\title{
Influence of a blend of functional oils or monensin on nutrient intake and digestibility, ruminal fermentation and milk production of dairy cows
}

\author{
E. Ferreira de Jesus ${ }^{b}$, T.A. Del Valle ${ }^{a}$, G.D. Calomeni ${ }^{a}$, T.H. Silva ${ }^{a}$, C.S. Takiya ${ }^{a}$, \\ T.H.A. Vendramini ${ }^{a}$, P.G. Paiva ${ }^{a}$, G.G. Silva ${ }^{a}$, A.S. Netto ${ }^{c}$, F.P. Rennó ${ }^{a}, *$ \\ a Department of Animal Nutrition and Production, University of Sao Paulo, Pirassununga, Brazil \\ b Department of Animal Science, UNESP - Universidade Estadual Paulista "Júlio de Mesquita Filho", Jaboticabal, Brazil \\ c Department of Animal Sciences, Faculty of Animal Science and Food Engineering, University of Sao Paulo, Pirassununga, Brazil
}

\section{A R T I C L E I N F O}

\section{Article history:}

Received 1 February 2016

Received in revised form 31 May 2016

Accepted 1 June 2016

\section{Keywords:}

Additives

Antimicrobial

Cashew nut shell liquid

Castor oil

Ionophore

Phenolic lipids

\begin{abstract}
A B S T R A C T
Cashew nut shell liquid (CNSL) and castor oil (CO) are considered functional oils since they present antitumor, antioxidant, gastroprotective, and antibiotic properties. The objective of this study was to evaluate the effects a commercial blend of functional oils (CNSL and $\mathrm{CO}$ ) and monensin supplementation on nutrient intake and total tract apparent digestibility, ruminal fermentation, milk yield and composition, $\mathrm{N}$ utilization, microbial protein synthesis, and blood metabolites of dairy cows. Twenty-four multiparous Holstein cows (150.2 \pm 61.4 days in milk, $619 \pm 76 \mathrm{~kg}$ of BW and $29.1 \pm 4.0 \mathrm{~kg} / \mathrm{d}$ of milk yield, mean \pm SD) were used in a replicated $3 \times 3$ Latin square experimental design, in which six ruminally cannulated cows were used to assess ruminal fermentation. The animals were randomly assigned to one of the following three treatments: control (CON; without additive); $500 \mathrm{mg} / \mathrm{kg}$ DM of functional oil (FO; commercial blend of CNSL and CO), and $22 \mathrm{mg} / \mathrm{kg}$ DM of monensin sodium (MON). The treatments did not affect either nutrient intake or digestibility of diets. Both feed additives provided an increase in ruminal propionate molar proportion compared to CON. In addition, FO increased ruminal propionate concentration when compared to MON and CON. Although both additives increased $(\mathrm{P}<0.01)$ milk and protein yields, MON had lower milk fat concentration compared to CON, not differing from FO. Monensin and FO increased milk nitrogen excretion.

Neither rumen microbial $\mathrm{N}$ synthesis nor blood glucose concentration were changed by the supplements. Finally, FO decreased $(\mathrm{P}<0.001)$ blood urea concentration compared to CON or MON, besides increasing milk yield without altering nutrient intake; thus, it might be an alternative to monensin in lactating cow diets.
\end{abstract}

(c) 2016 Elsevier B.V. All rights reserved.

Abbreviations: aADF, acid detergent fiber; aNDF, neutral detergent fiber; BW, body weight; BFCA, branched-chain fatty acids; CNSL, cashew nut shell liquid; $\mathrm{CO}$, castor oil; $\mathrm{CON}$, control; $\mathrm{CP}$, crude protein; DM, dry matter; FCM, fat corrected milk; FO, functional oils; $\mathrm{MON}$, monensin; $\mathrm{N}$, nitrogen; $\mathrm{NH}_{3}-\mathrm{N}$, ammonia nitrogen; standard error of the mean, SD; volatile fatty acid, VFA.

* Corresponding author.

E-mail address: francisco.renno@usp.br (F.P. Rennó). 


\section{Introduction}

After the banning of monensin (MON) as a growth promoter by the European Union (Regulation 1831/2003/EC), natural compounds have been evaluated to replace MON in dairy cow diets. Functional oils (FO), including cashew nut shell liquid (CNSL) and castor oil (CO), are chemical substances extracted from various plants by distillation, compression or using solvents, providing health benefits besides their nutritive properties. Cashew nut shell liquid and CO have been considered potential rumen modulators because beyond antimicrobial effects, these oils have shown anti-inflamatory (Vieira et al., 2000), anti-oxidative (Trevisan et al., 2006), and gastroprotective (Hamad and Mubofu, 2015) properties which classify them as components of livestock functional feeds.

Cashew nut shell liquid is a by-product of the cashew industry containing phenolic compounds (eg anacardic acid, cardanol, and cardol) that inhibit Gram-positive bacteria growth and allow the proliferation of Gram-negative bacteria, thereby increasing ruminal propionate production (Van Nevel et al., 1971; Ipharraguerre and Clark, 2003). Watanabe et al. (2010) reported that CNSL linearly increased the total volatile fatty acid (VFA) concentrations and propionate production in an in vitro fermentation study. Castor oil, obtained from pressing castor seeds, is rich in ricinoleic acid which has shown antimicrobial properties (Ferreira et al., 2002). Additionally, Ramos Morales et al. (2012) reported a reduction in acetate and an increase in propionate for ruminal digestion in sheep supplemented with ricinoleic acid. A blend of CNSL and CO, marketed in Brazil (Essential ${ }^{\circledR}$, Oligo Basics Agroindustry Ltda., Cascavel, Brazil) was primarily used as anticoccidial in broilers (Murakami et al., 2014) and more recently as a feed additive to ruminants. While some authors have shown that the blend of FO is able to improve dry matter (DM) digestibility (Cruz et al., 2014), feed efficiency (Valero et al., 2014), and meat quality (Prado et al., 2015a) of beef steers, such information is scarce for dairy cattle performance.

The objective of this study was to compare the effects of a mixture of CSNL and CO with MON on nutrient intake and total tract apparent digestibility, ruminal fermentation, milk yield and composition, $\mathrm{N}$ utilization efficiency, microbial protein synthesis, and blood metabolites of lactating dairy cows. The hypothesis was that the FO blend could replace MON in dairy cow diets without reducing the productive performance.

\section{Material and methods}

The experiment was approved by the Animal Research Ethics Committee of the School of Veterinary Medicine and Animal Science, University of São Paulo-USP (approval number: 6134130415).

\subsection{Animals and experimental design}

The experiment was performed at the Dairy Cattle Research Laboratory, University of São Paulo in Pirassununga-SP, Brazil. Twenty-four multiparous Holstein cows $(150.2 \pm 61.4$ days in milk, $619 \pm 76 \mathrm{~kg}$ of BW and $29.1 \pm 4.0 \mathrm{~kg} / \mathrm{d}$ of milk yield at the start of the experiment, mean \pm SD) were blocked by the milk yield, days in milk, and live weight in a replicated $3 \times 3$ Latin square design experiment. Six of the animals were ruminally fistulated to assess ruminal fermentation parameters. The three periods of the experiment were composed each of 14 days of adaptation to treatments and 7 days for sampling and data analysis. Cows were randomly assigned to receive one of the three treatments in the first period, and then diets were switched among cows for the second and third periods, according the Latin Square design. The three treatments were control (CON; without additive), $500 \mathrm{mg} / \mathrm{kg}$ DM of functional oil (FO; commercial blend of CNSL and CO-Essential ${ }^{\circledR}$, Oligo Basics Agroindustrial Ltda.), and $22 \mathrm{mg} / \mathrm{kg}$ DM of monensin sodium (MON-Rumensin ${ }^{\circledR}$, Elanco Animal Health, São Paulo, Brazil). The two dietary supplements (MON and FO) were added to a mineral mixture and then to a concentrate. The basal diet (Table 1) was formulated according to the NRC (2001) and was offered as a Total Mixed Ration at a 50:50 ratio between the morning and afternoon feedings $(0700 \mathrm{~h}-1300 \mathrm{~h})$. Refusals were restricted to $5-10 \%$ of feed offered (on wet-basis). Throughout the experiment, cows were housed in individual pens $\left(17.5 \mathrm{~m}^{2}\right.$ of area), with sand bedding, individual feed bunks and forced ventilation. The corn silage DM content was measured twice a week and diet adjustments were made when necessary.

\subsection{Nutrient intake and total tract apparent digestibility}

Corn silage and ryegrass haylage samples of $0.3 \mathrm{~kg}$ were daily collected during each 7 -d sampling period to form a composite sample (on wet-basis). Concentrate ingredients were sampled $(0.5 \mathrm{~kg})$ during blending $(\mathrm{n}=4)$ and individual orts (12.5\% of daily orts) were taken daily within each 7-d sampling period. Composite samples of feed, orts and feces were dried in a forced-air oven at $55^{\circ} \mathrm{C}$ for $72 \mathrm{~h}$, and ground in a Wiley mill (Arthur H. Thomas, Philadelphia, PA, USA) to pass through a $1 \mathrm{~mm}$ screen.

The contents of DM (method 930.15; AOAC, 2000), organic matter-OM (DM-ash), crude protein-CP (N $\times 6.25$, method 984.13; AOAC, 2000), and ether extract-EE (method 920.39, AOAC, 2000) were evaluated in all samples. The content of neutral detergent fiber (aNDF), acid detergent fiber (aADF), and lignin (sa) of samples were measured according to the methods described by Van Soest et al. (1991), and the results were expressed with residual ash. The NDF analysis was determined using $\alpha$-amylase without sodium sulfite (TE-149 fiber analyzer, Tecnal Equipment for Laboratory Inc., Piracicaba, Brazil). Total digestible nutrient was calculated according to NRC (2001) equations. Net energy of lactation was estimated 
Table 1

Ingredients and chemical composition of the basal diet.

\begin{tabular}{|c|c|}
\hline Item & Diet \\
\hline \multicolumn{2}{|l|}{ Ingredient (g/kg DM) } \\
\hline Corn silage & 368 \\
\hline Ryegrass haylage & 112 \\
\hline Ground corn & 219 \\
\hline Soybean meal & 135 \\
\hline Soybean hulls & 49.8 \\
\hline Wheat middling & 40.0 \\
\hline Corn gluten meal & 31.9 \\
\hline Mineral mixture ${ }^{1}$ & 18.0 \\
\hline Limestone & 12.1 \\
\hline Sodium bicarbonate & 8.10 \\
\hline Urea & 3.10 \\
\hline Sodium chloride & 1.80 \\
\hline Ammonium sulfate & 0.90 \\
\hline \multicolumn{2}{|l|}{ Chemical (g/kg DM) } \\
\hline Dry matter (g/kg natural matter) & 641 \\
\hline Neutral detergent fiber & 369 \\
\hline Acid detergent fiber & 236 \\
\hline Crude protein & 157 \\
\hline Ash & 91.2 \\
\hline Lignin & 35.5 \\
\hline Ether extract & 27.9 \\
\hline Non-fiber carbohydrate ${ }^{2}$ & 355 \\
\hline Net energy of lactation ${ }_{3 \times}{ }^{3}(\mathrm{MJ} / \mathrm{kg} \mathrm{DM})$ & 6.53 \\
\hline
\end{tabular}

1 Contained per kilogram of the product: 88.0 g Ca, $42.0 \mathrm{~g} \mathrm{P}, 18.0 \mathrm{~g} \mathrm{~S}, 45.0 \mathrm{~g} \mathrm{Mg}, 123.0 \mathrm{Na}, 0.22 \mathrm{mg} \mathrm{Co,} 22.0 \mathrm{mg} \mathrm{Cu}, 20.0 \mathrm{mg}$ Cr, $35 \mathrm{mg}$ Fe, $1.20 \mathrm{mg}$ I, $28 \mathrm{mg}$ Mn, $0.70 \mathrm{mg}$ Se, $90.0 \mathrm{mg} \mathrm{Zn}, 80 \mathrm{mg}$ Biotin, $7000 \mathrm{IU}$ vitamin A, $2000 \mathrm{IU}$ vitamin D, and 50 IU vitamin E.

$2 \mathrm{NFC}=1000-[(\mathrm{CP}-\mathrm{CP}$ of urea $+\%$ urea $)+\mathrm{NDF}+\mathrm{EE}+\mathrm{ash}]$, from Hall $(2000) . \mathrm{CP}=$ crude protein, NDF $=$ neutral detergent fiber, and $\mathrm{EE}=$ ether extract.

3 Estimated according to NRC (2001).

as described by Weiss et al. (1992). Finally, non-fiber carbohydrate (NFC) was ascertained through equation of Hall (2000): $\mathrm{NFC}=100-[(\mathrm{CP}-\mathrm{CP}$ from urea + urea $)+\mathrm{NDF}+\mathrm{EE}+\mathrm{ash}]$, with values expressed in percentage.

Fecal samples $(0.3 \mathrm{~kg})$ were collected directly from the rectum of each cow every $9 \mathrm{~h}$ from day 16 until day 18 of each experimental period, representing a collection every $3 \mathrm{~h}$ in a period of $24 \mathrm{~h}$, to estimate the amount of excreted nutrient a day. After collection, samples were stored at $-20^{\circ} \mathrm{C}$, homogenizing them (wet basis) at the end of each evaluation period to form composite samples for each animal. Afterwards, samples were dried in a forced-air oven at $55^{\circ} \mathrm{C}$ for $72 \mathrm{~h}$, and ground in a Wiley mill (Arthur H. Thomas) to pass through a $2 \mathrm{~mm}$ screen. Ground samples (2-mm screen) of feed ingredients, orts and feces were placed in non-woven textile bags $(5 \times 5 \mathrm{~cm})$ following the recommendation of a maximum of $20 \mathrm{mg}$ of DM/ $/ \mathrm{cm}^{2}$ (Nocek, 1988). These samples were then incubated for $288 \mathrm{~h}$ in the rumen of two Holstein cows, previously adapted to a control diet as described in the technique of Casali et al. (2008). After removal from the rumen, the bags were washed in running tap water, dried at $55^{\circ} \mathrm{C}$ in a forced-air oven for $72 \mathrm{~h}$, and analyzed for $A D F$ content as described above. Fecal samples were evaluated for NDF, CP, and EE according to AOAC (2000) as previously described. The indigestible acid detergent fiber (iADF) was used as an internal marker to analyze total tract digestion, being calculated by the following equations:

$$
\begin{aligned}
& \text { Digestibility of DM }=100-\left[100 \times\left(\frac{\% \text { iADF intake }}{\% \text { iADF in feces }}\right)\right] \\
& \text { Digestibility of nutrient }=100-\left[100 \times\left(\frac{\% \text { iADF intake }}{\% \text { iADF in feces }}\right) \times\left(\frac{\% \text { nutrient in feces }}{\% \text { nutrient intake }}\right)\right]
\end{aligned}
$$

\subsection{Ruminal fermentation}

Ruminal digesta were collected on day 20 of each experimental period, always by the same technician, withdrawing equal amounts of digesta from multiples sites within the rumen of cannulated cows (anterior dorsal, anterior ventral, medium ventral, posterior dorsal, and posterior ventral), before the morning feeding (time 0 ) and 2, 4, 6, 8, 10, 12, 14, 16 and $24 \mathrm{~h}$ relative to the morning feeding. Immediately after each collection, samples were pooled and strained in four layers of cheesecloth to obtain ruminal fluid $(250 \mathrm{~mL})$. The ruminal fluid $\mathrm{pH}$ was measured using a potentiometer (MB-10, Marte, Santa Rita Sapucai, Brazil). Aliquots of $1600 \mu \mathrm{L}$ of these samples were mixed with $400 \mu \mathrm{L}$ methanoic acid $\left(98-100 \% \mathrm{H}_{2} \mathrm{CO}_{2}\right)$, being centrifuged at $7000 \mathrm{~g}$ for $15 \mathrm{~min}$ at $4{ }^{\circ} \mathrm{C}$, and the supernatant of each sample was stored at $-20^{\circ} \mathrm{C}$ for VFA analysis. Also, aliquots of $2 \mathrm{~mL}$ were mixed with $1 \mathrm{~mL}$ of sulfuric acid $\left(0.5 \mathrm{Mol} / \mathrm{L} \mathrm{H}_{2} \mathrm{SO}_{4}\right)$ and stored at $-20^{\circ} \mathrm{C}$ for subsequent analysis of ammonia nitrogen $\left(\mathrm{N}-\mathrm{NH}_{3}\right)$ by the colorimetric phenol-hypochlorite method (Broderick and Kang, 1980). 
Ruminal VFA were measured using a gas chromatograph (GC-2014, Shimadzu, Tokyo, Japan) equipped with a capillary column (Stabilwax, Restek, Bellefonte, USA). The gases used were helium as the carrier gas ( $8.01 \mathrm{~mL} / \mathrm{min}$ flow), hydrogen as the fuel gas (pressure of $60 \mathrm{kPa}$ ), and synthetic air as the oxidizer gas (pressure of $40 \mathrm{kPa}$ ). The steamer temperature was set at $220^{\circ} \mathrm{C}$, the ionization detector flames at $250^{\circ} \mathrm{C}$, and the separation column at $145^{\circ} \mathrm{C}$ for 3 min, which was then raised $10^{\circ} \mathrm{C} / \mathrm{min}$ up to $200^{\circ} \mathrm{C}$.

\subsection{Milk yield and composition}

Cows were milked daily at $0600 \mathrm{~h}$ and $1530 \mathrm{~h}$ and milk yield was recorded electronically (Alpro ${ }^{\circledR}$, DeLaval, Tumba, Sweden). Based on milk yield, samples were collected from each cow on days 15, 16 and 17 of each experimental period, being directly analyzed for fat, protein and lactose content by infrared methodology (Lactoscan ${ }^{\circledR}$, Entelbra, São Paulo, Brazil). Sub-samples of $20 \mathrm{~mL}$ were deproteinized according to Broderick and Clayton (1997) and subsequently analyzed for milk urea nitrogen by colorimetric commercial kits (Bioclin ${ }^{\circledR}$, Belo Horizonte, Brazil) and readings were performed by a semiautomatic biochemistry analyzer (SBA-200, CELM ${ }^{\circledR}$, São Caetano do Sul, Brazil). The 3.5\% fat-corrected milk (FCM) was calculated according to Sklan et al. (1992): 3.5\% FCM $=(0.432+0.165 \times$ milk fat $) \times$ milk yield $(\mathrm{kg} / \mathrm{d})$.

\subsection{Nitrogen utilization and microbial $N$ synthesis}

Nitrogen excreted in milk was calculated based on the following equation: milk $\mathrm{N}(\mathrm{g} / \mathrm{d})=$ milk $\mathrm{CP}$ concentration $(\mathrm{g} / \mathrm{kg}) \times$ milk yield $(\mathrm{kg} / \mathrm{d}) \div 6.38$. Nitrogen excreted in feces was calculated based on the equation: fecal $\mathrm{N}(\mathrm{g} / \mathrm{d})=\mathrm{CP}$ in feces $(\mathrm{g} / \mathrm{kg}) \times$ DM fecal excretion $(\mathrm{kg} / \mathrm{d}) \div 6.25$. Samples of urine were also collected at the same time as feces as described previously. After being collected, urine samples were filtered and aliquots of $10 \mathrm{~mL}$ were diluted in $40 \mathrm{~mL}$ of $0.036 \mathrm{~N}$ sulfuric acid to avoid bacterial destruction of purine derivatives and uric acid precipitation, being stored at $-20^{\circ} \mathrm{C}$. Non-diluted urine samples were also stored at $-20^{\circ} \mathrm{C}$, for further assessment of nitrogen and creatinine concentrations. Total urine volume was estimated according to Chizzotti et al. (2008), and urine N was determined according to AOAC (method 984.13, AOAC, 2000); hence, urinary $\mathrm{N}$ excretion was calculated by multiplying urine $\mathrm{N}$ by urine volume.

Daily urinary volume was estimated based on creatinine concentrations in urine. Creatinine and uric acid concentrations were determined using commercial kits (Bioclin ${ }^{\circledR}$, Belo Horizonte, Brazil) by colorimetric method and readings were performed in a semi-automatic biochemistry analyzer (SBA-200, CELM ${ }^{\circledR}$ ). The daily creatinine urinary excretion was estimated assuming that daily rate of creatinine excretion as a ratio to BW is fixed at $24.05 \mathrm{mg} / \mathrm{kg}$ BW (Chizzotti et al., 2008). Body weights were measured using an electronic livestock scale for large animals (DeLaval), after milking and before the morning feeding on days 7 and 21 of each experimental period.

Microbial N synthesis was determined according to Chen and Gomes (1992). Allantoin in urine and in milk were analyzed by a colorimetric method (Chen and Gomes, 1992). Milk samples of $10 \mathrm{~mL}$ were mixed with $5 \mathrm{~mL}$ of trichloroacetic acid (25\%), rested for $5 \mathrm{~min}$ and then being filtered through paper filter (14- $\mu \mathrm{m}$ pore size) to obtain deproteinized milk samples. The total excretion of purine derivatives (PD, $\mathrm{mmol} / \mathrm{d}$ ) was calculated as the sum of allantoin and uric acid amounts excreted in urine and milk (Orellana Boero et al., 2001). The absorbed PD ( $\mathrm{PD}_{\mathrm{abs}}, \mathrm{mmol} / \mathrm{d}$ ) were calculated as follows: $\mathrm{PD}_{\mathrm{abs}}=\left(\mathrm{PD}-0.385 \times \mathrm{BW}^{0.75}\right) \div 0.84$; in which 0.84 represents the recovery of $\mathrm{PD}_{\mathrm{abs}}$ as $\mathrm{PD}$ and $0.385 \times \mathrm{BW}^{0.75}$ represents the endogenous excretion of PD (Chen and Gomes, 1992). The ruminal synthesis of nitrogen compounds ( $\mathrm{N}_{\text {mic }} \mathrm{g}$ of $\left.\mathrm{N} / \mathrm{d}\right)$ was calculated based on the $\mathrm{PD}_{\mathrm{abs}}$, through the equation of Chen and Gomes (1992): $\mathrm{N}_{\text {mic }}=\left(70 \times \mathrm{PD}_{\mathrm{abs}}\right) \div(0.83 \times 0.134 \times 1000)$; in which 70 is the $\mathrm{N}$ purine derivative content $(\mathrm{mg} \mathrm{N} / \mathrm{mol}), 0.134$ is the ratio between $\mathrm{N}$ purine derivatives and $\mathrm{N}$ microbial (Valadares et al., 1999), and 0.83 is the intestinal digestibility of microbial purines.

\subsection{Blood profile}

On day 17 of each period, prior to the morning feeding, blood samples were collected from all cows by puncture of coccygeal vessels into sterile vacutainers without clot activator (BD Vacutainer systems, Franklin Lakes, NJ, USA). After clotting, samples were centrifuged for $15 \mathrm{~min}$ at $2000 \mathrm{~g}$ and $4{ }^{\circ} \mathrm{C}$; the supernatant serum was transferred into labeled plastic tubes and stored at $-20^{\circ} \mathrm{C}$. Blood serum was analyzed for glucose, urea, aspartate-aminotransferase, and gamma-glutamyl transferase using colorimetric commercial kits (Bioclin ${ }^{\circledR}$ ) and readings were performed by a semi-automatic biochemistry analyzer (SBA-200, CELM $\left.{ }^{\circledR}\right)$.

\subsection{Statistical analyses}

Data were analyzed with PROC MIXED (SAS Inst. Inc., Cary, NC) as a $3 \times 3$ Latin square design according to the statistical model below:

$$
Y_{i j k l}=\mu+T_{i}+P_{j}+S_{k}+A_{l}\left(S_{i}\right)+e_{i j k}
$$

Wherein: $Y_{i j k l}=$ dependent variable; $\mu=$ overall mean; $\mathrm{T}_{i}=$ fixed effect of treatment $(i=1$ to 3$) ; P_{j}=$ fixed effect of period $(j=1$ to 3$) ; S_{\mathrm{k}}=$ fixed effect of square $(k=1$ to 8$) ; A_{l}\left(S_{i}\right)$ random effect of animal within square $(l=1$ to 24$)$ and $e_{i j k l}=$ residual error. 
Table 2

Influence of a blend of functional oils or monensin on nutrient intake and total tract apparent digestibility of lactating dairy cows.

\begin{tabular}{|c|c|c|c|c|c|c|}
\hline \multirow[b]{2}{*}{ Item } & \multicolumn{3}{|c|}{ Treatment $^{1}$} & \multirow[b]{2}{*}{ Mean } & \multirow[b]{2}{*}{ SEM } & \multirow[b]{2}{*}{$P$-value } \\
\hline & $\mathrm{CON}$ & FO & MON & & & \\
\hline \multicolumn{7}{|l|}{ Intake (kg/d) } \\
\hline Dry matter & 24.6 & 25.1 & 24.7 & 24.8 & 0.443 & 0.455 \\
\hline Neutral detergent fiber & 8.40 & 8.65 & 8.52 & 8.52 & 0.161 & 0.271 \\
\hline Crude protein & 3.93 & 4.02 & 3.96 & 3.97 & 0.071 & 0.395 \\
\hline Ether extract & 0.70 & 0.72 & 0.71 & 0.71 & 0.013 & 0.144 \\
\hline Non-fiber carbohydrate ${ }^{2}$ & 9.56 & 9.82 & 9.76 & 9.71 & 0.175 & 0.257 \\
\hline Net energy of lactation $_{3 \mathrm{x}}(\mathrm{MJ} / \mathrm{d})^{3}$ & 144 & 145 & 142 & 144 & 2.468 & 0.352 \\
\hline \multicolumn{7}{|l|}{ Intake (\% live weight) } \\
\hline Dry matter & 3.89 & 3.97 & 3.90 & 3.93 & 0.066 & 0.302 \\
\hline Neutral detergent fiber & 1.33 & 1.37 & 1.34 & 1.35 & 0.023 & 0.235 \\
\hline \multicolumn{7}{|l|}{ Coefficient of digestibility } \\
\hline Dry matter & 0.67 & 0.67 & 0.67 & 0.67 & 0.006 & 0.746 \\
\hline Neutral detergent fiber & 0.63 & 0.62 & 0.62 & 0.62 & 0.006 & 0.299 \\
\hline Crude protein & 0.69 & 0.69 & 0.71 & 0.70 & 0.006 & 0.142 \\
\hline Ether extract & 0.85 & 0.84 & 0.83 & 0.84 & 0.005 & 0.441 \\
\hline
\end{tabular}

1 Control (CON), no additive; Functional Oil (FO), dietary inclusion of $500 \mathrm{mg} / \mathrm{kg}$ DM of a blend of functional oils composed by cashew nut liquid and castor oil; and Monensin (MON), dietary inclusion of $22 \mathrm{mg} / \mathrm{kg}$ DM of monensin.

$2 \mathrm{NFC}=1000-[(\mathrm{CP}-\mathrm{CP}$ of urea $+\%$ urea $)+\mathrm{NDF}+\mathrm{EE}+\mathrm{ash}]$, from Hall $(2000) . \mathrm{CP}=$ crude protein, NDF $=$ neutral detergent fiber, and $\mathrm{EE}=\mathrm{ether}$ extract.

3 Estimated according to NRC (2001).

Table 3

Influence of a blend of functional oils or monensin on ruminal fermentation parameters of lactating dairy cows.

\begin{tabular}{|c|c|c|c|c|c|c|c|c|}
\hline \multirow[t]{2}{*}{ Item } & \multicolumn{3}{|c|}{ Treatment $^{1}$} & \multirow[t]{2}{*}{ Mean } & \multirow[t]{2}{*}{ SEM } & \multicolumn{3}{|l|}{ P-value } \\
\hline & $\mathrm{CON}$ & FO & MON & & & Treatment & Time & Treatment*Time \\
\hline $\mathrm{pH}$ & 6.31 & 6.25 & 6.30 & 6.29 & 0.026 & 0.115 & $<0.001$ & 0.943 \\
\hline \multicolumn{9}{|l|}{ Fatty acids (mmol/100 mmol) } \\
\hline Acetate & 61.1 & 60.7 & 61.1 & 61.0 & 0.170 & 0.970 & $<0.001$ & 0.978 \\
\hline Propionate & $19.9^{b}$ & $21.0^{\mathrm{a}}$ & $20.7^{\mathrm{a}}$ & 20.5 & 0.193 & 0.006 & $<0.001$ & 0.999 \\
\hline Butyrate & 13.8 & 13.3 & 13.4 & 13.5 & 0.100 & 0.525 & 0.014 & 0.956 \\
\hline Valerate & 1.47 & 1.50 & 1.46 & 1.48 & 0.017 & 0.397 & $<0.001$ & 0.960 \\
\hline Total BCFA ${ }^{2}$ & 3.52 & 3.68 & 3.31 & 3.50 & 0.052 & 0.277 & 0.024 & 0.778 \\
\hline \multicolumn{9}{|l|}{ Fatty acids (mmol/L) } \\
\hline Acetate & 84.2 & 83.4 & 79.0 & 82.4 & 0.931 & 0.366 & $<0.001$ & 0.283 \\
\hline Propionate & $27.3^{\mathrm{b}}$ & $29.5^{\mathrm{a}}$ & $27.4^{\mathrm{b}}$ & 28.2 & 0.566 & 0.037 & $<0.001$ & 0.919 \\
\hline Butyrate & 19.1 & 17.9 & 17.4 & 18.2 & 0.238 & 0.203 & $<0.001$ & 0.235 \\
\hline Valerate & 2.05 & 2.09 & 1.93 & 2.02 & 0.041 & 0.319 & $<0.001$ & 0.810 \\
\hline Total BCFA ${ }^{2}$ & $4.90^{\mathrm{a}}$ & $5.03^{a}$ & $4.27^{\mathrm{b}}$ & 4.73 & 0.095 & 0.004 & $<0.001$ & 0.460 \\
\hline Total VFA ${ }^{3}$ & 138 & 138 & 130 & 135 & 1.728 & 0.419 & $<0.001$ & 0.335 \\
\hline Acetate to propionate ratio & 3.08 & 2.82 & 2.88 & 3.01 & 0.035 & 0.849 & $<0.001$ & 0.969 \\
\hline
\end{tabular}

a,b Values in the same row with a different superscript differ significantly.

1 Control (CON), no additive; Functional Oil (FO), dietary inclusion of $500 \mathrm{mg} / \mathrm{kg}$ DM of a blend of functional oils composed by cashew nut liquid and castor oil; and Monensin (MON), dietary inclusion of $22 \mathrm{mg} / \mathrm{kg}$ DM of monensin.

2 Total branched-chain fatty acids.

3 Total volatile fatty acids.

Ruminal fermentation characteristics (VFA, $\mathrm{pH}, \mathrm{NH}_{3}-\mathrm{N}$ ) were analyzed as repeated measures by adding to the previous model sampling time $(0,2,4,6,8,10,12,14,16$, and $24 \mathrm{~h}$ relative to the morning feeding) and its interaction with treatments as fixed effects. A first-order autoregressive covariance structure [AR (1)] was used for data analysis based on the smallest Akaike's information criterion (AIC) values. Other covariance structures tested included compound symmetry, heterogeneous compound symmetry, unstructured, autoregressive 1 and heterogeneous autoregressive 1 . Differences among treatments were analyzed by the least significant difference test (PDIFF). The values in tables were adjusted by LSMEANS and the significant level was set at $\mathrm{P}<0.05$.

\section{Results}

Overall, treatments had no effect on nutrient intake ( $\mathrm{kg} / \mathrm{d}$ and\% live weight) and total apparent digestibility ( $\mathrm{P} \geq 0.142$, Table 2), not altering $(\mathrm{P} \geq 0.115)$ ruminal $\mathrm{pH}$ and $\mathrm{NH}_{3}-\mathrm{N}$ concentration (Table 3$)$. Both $\mathrm{MON}$ and $\mathrm{FO}$ supplementation increased $(\mathrm{P}=0.006)$ ruminal propionate proportion compared to CON $(20.9 \pm 0.387$ vs. $19.9 \pm 0.550 \mathrm{mmol} / 100 \mathrm{mmol}$, respectively $)$. Furthermore, cows fed FO exhibited the highest propionate concentration $(\mathrm{P}=0.037)$, and the ones fed MON showed similar 


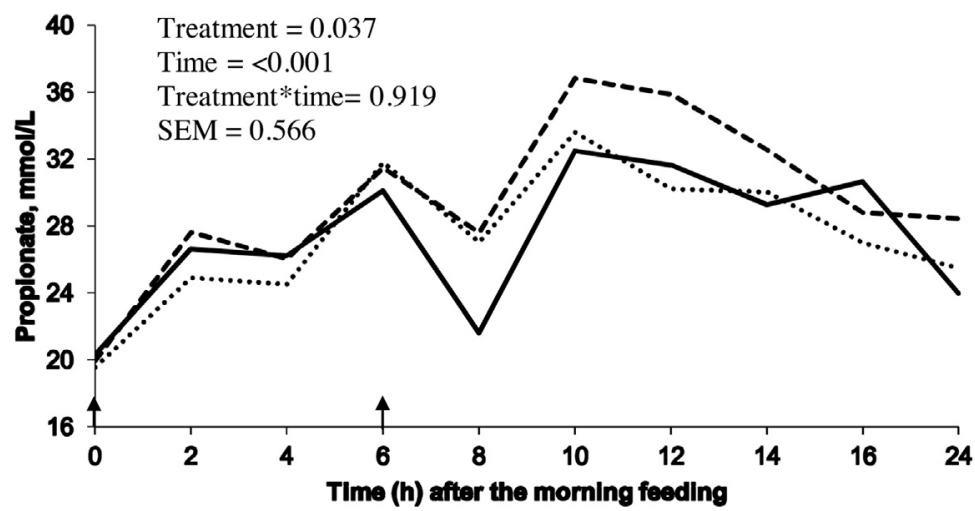

Control $^{\mathrm{b}}(-)$, Functional Oil $^{\mathrm{a}}(--)$, and Monensin ${ }^{\mathrm{a}}(\ldots \ldots$.$) ; Feeding time (\uparrow)$.

Fig. 1. Influence of a blend of functional oils or monensin on ruminal propionate concentration of lactating dairy cows. Control, no additive; Functional Oil (FO), dietary inclusion of $500 \mathrm{mg} / \mathrm{kg} \mathrm{DM}$ of an oil composed by cashew nut liquid and castor oil; and Monensin (MON), dietary inclusion of $22 \mathrm{mg} / \mathrm{kg} \mathrm{DM}$ of sodic monensin. Different superscripts in treatments differ significantly.

Table 4

Influence of a blend of functional oils or monensin on milk yield and composition of dairy cows.

\begin{tabular}{|c|c|c|c|c|c|c|}
\hline \multirow[t]{2}{*}{ Item } & \multicolumn{3}{|c|}{ Treatment $^{1}$} & \multirow[t]{2}{*}{ Mean } & \multirow[t]{2}{*}{ SEM } & \multirow[t]{2}{*}{$P$-value } \\
\hline & CON & FO & MON & & & \\
\hline \multicolumn{7}{|l|}{ Yield (kg/d) } \\
\hline Milk & $25.9^{\mathrm{b}}$ & $27.1^{\mathrm{a}}$ & $27.2^{\mathrm{a}}$ & 26.7 & 0.659 & $<0.001$ \\
\hline FCM & 26.5 & 27.4 & 27.0 & 26.9 & 0.683 & 0.188 \\
\hline Fat & 0.94 & 0.97 & 0.94 & 0.95 & 0.027 & 0.400 \\
\hline Protein & $0.78^{\mathrm{b}}$ & $0.81^{\mathrm{a}}$ & $0.81^{\mathrm{a}}$ & 0.80 & 0.020 & 0.006 \\
\hline Lactose & $1.17^{\mathrm{b}}$ & $1.22^{\mathrm{a}}$ & $1.22^{\mathrm{a}}$ & 1.20 & 0.030 & 0.003 \\
\hline Efficiency $^{2}$ & 1.07 & 1.08 & 1.10 & 1.08 & 0.020 & 0.296 \\
\hline \multicolumn{7}{|l|}{ Proportion (g/kg) } \\
\hline Fat & $36.6^{\mathrm{a}}$ & $36.0^{\mathrm{a}, \mathrm{b}}$ & $34.6^{\mathrm{b}}$ & 35.7 & 0.673 & 0.025 \\
\hline Protein & 30.1 & 30.1 & 30.0 & 30.0 & 0.132 & 0.475 \\
\hline Lactose & $45.1^{\mathrm{a}, \mathrm{b}}$ & $45.2^{\mathrm{a}}$ & $44.8^{\mathrm{b}}$ & 45.0 & 0.331 & 0.046 \\
\hline Ureic N (mg/dL) & 8.12 & 8.25 & 8.46 & 8.29 & 0.168 & 0.545 \\
\hline
\end{tabular}

a,b Values in the same row with a different superscript differ significantly.

1 Control (CON), no additive; Functional Oil (FO), dietary inclusion of $500 \mathrm{mg} / \mathrm{kg}$ DM of a blend of functional oils composed by cashew nut liquid and castor oil; and Monensin (MON), dietary inclusion of $22 \mathrm{mg} / \mathrm{kg}$ DM of monensin.

propionate concentration those fed CON (Fig. 1). Total branched-fatty acids was lower $(\mathrm{P}=0.004)$ in the rumen of cows fed MON whether compared to FO or CON. Despite the differences found in ruminal propionate, the ratio acetate to propionate was not altered $(\mathrm{P}=0.849)$ by treatments; and no interaction between diet and time was found.

Although milk production was increased $(\mathrm{P}<0.001)$ by FO or MON supplementations (Table 4$)$, the FCM yield was not affected $(P=0.188)$ by the treatments. Milk protein and lactose yield were also increased $(P \leq 0.006)$ with FO and MON addition. Milk fat concentration of cows fed MON and FO were similar; however, MON-fed cows had lower milk fat concentration than the CON-fed ones. Interestingly, FO promoted higher milk lactose concentration compared to MON, but not differing from CON. It is noteworthy mention that treatments had no effect on milk urea nitrogen.

Supplementation with FO or MON increased $(P=0.006)$ milk N excretion in comparison with CON (Table 5). However, microbial protein synthesis was not affected by any of treatments. It is interesting to highlight that FO reduced $(\mathrm{P}<0.001)$ the amount of urea in blood in relation to both CON and MON. Besides, the blood markers of liver damage such as aspartateaminotransferase and gamma-glutamyl transferase were not altered by dietary treatments.

\section{Discussion}

Nutrient intake and total apparent digestibility were not altered by treatments evaluated. The assessed feed intake mechanisms are related to a short-term regulation, especially with respect to hepatic fuel oxidation (Allen et al., 2009). This process together with ATP production, over a few minutes, may greatly fluctuate and indirectly affect satiety centers, thus increasing or decreasing feed intake (Allen, 2000). Since no differences were observed on nutrient digestibility, neither interactions of diet and time were reported on ruminal fermentation; liver fuel oxidation might have been similar.

Some studies have also reported the lack of effects of MON on DM intake and digestibility of dairy cows (Akins et al., 2014; Prado et al., 2015b; Vendramini et al., 2016). Besides of that, data of FO effects on dairy cow performance are still scarce in 
Table 5

Influence of a blend of functional oils or monensin on nitrogen utilization, microbial protein synthesis, and blood profile of lactating dairy cows.

\begin{tabular}{|c|c|c|c|c|c|c|}
\hline \multirow[t]{2}{*}{ Item } & \multicolumn{3}{|c|}{ Treatment $^{1}$} & \multirow[t]{2}{*}{ Mean } & \multirow[t]{2}{*}{ SEM } & \multirow[t]{2}{*}{ P-value } \\
\hline & $\mathrm{CON}$ & FO & MON & & & \\
\hline \multicolumn{7}{|l|}{$\mathrm{N}$ utilization $(\mathrm{g} / \mathrm{d})$} \\
\hline $\mathrm{N}$ intake & 629 & 643 & 633 & 635 & 11.30 & 0.391 \\
\hline Urinary $\mathrm{N}$ & 264 & 287 & 286 & 279 & 12.14 & 0.575 \\
\hline Fecal N & 190 & 186 & 181 & 185 & 4.82 & 0.476 \\
\hline Milk N & $122^{\mathrm{b}}$ & $127^{\mathrm{a}}$ & $127^{\mathrm{a}}$ & 125 & 3.12 & 0.006 \\
\hline Microbial N (g/d) & 351 & 379 & 397 & 376 & 23.30 & 0.608 \\
\hline Microbial N synthesis efficiency ${ }^{2}$ & 133 & 140 & 153 & 142 & 8.98 & 0.492 \\
\hline \multicolumn{7}{|l|}{ Blood profile } \\
\hline Glucose (mg/dL) & 43.2 & 43.9 & 44.5 & 43.9 & 1.09 & 0.830 \\
\hline Urea $(\mathrm{mg} / \mathrm{dL})$ & $37.3^{\mathrm{a}}$ & $32.4^{\mathrm{b}}$ & $39.2^{\mathrm{a}}$ & 37.1 & 0.90 & $<0.001$ \\
\hline Aspartate-aminotransferase (U/L) & 66.9 & 70.8 & 68.6 & 68.8 & 1.17 & 0.173 \\
\hline Gamma-glutamyl transferase (U/L) & 29.1 & 29.5 & 30.6 & 28.6 & 2.41 & 0.417 \\
\hline
\end{tabular}

a,b Values in the same row with a different superscript differ significantly.

1 Control (CON), no additive; Functional Oil (FO), dietary inclusion of $500 \mathrm{mg} / \mathrm{kg}$ DM of a blend of functional oils composed by cashew nut liquid and castor oil; and Monensin (MON), dietary inclusion of $22 \mathrm{mg} / \mathrm{kg}$ DM of monensin.

2 Synthesis of microbial crude protein $(\mathrm{g}) /$ total digestible nutrient intake $(\mathrm{kg})$

literature. Purevjav (2011) fed beef steers with FO at $250 \mathrm{mg} / \mathrm{kg}$ DM and did not find differences on DM intake compared to those animals fed MON or CON. Similarly, supplementing FO at $3 \mathrm{~g} / \mathrm{d}$ in diets of finishing beef cattle had no effect on DM intake (Cruz et al., 2014) and nutrient digestibility (Valero et al., 2014). Additionally, other studies that evaluated CNSL in diets of dairy cows also described no differences on DM intake and nutrient digestibility (Shinaki et al., 2012; Coutinho et al., 2014; Branco et al., 2015).

When supplemented with MON and FO, lactating cows had increased propionate concentration in rumen. Such result has been reported for MON-fed cattle since 70' (Raun et al., 1974); emphasizing that these results have been consistently achieved regardless which diet was adopted or evaluated lactation stage (Prado et al., 2015a,b; Vendramini et al., 2016). Regarding Russell (1996), this increase in ruminal propionate concentration is attributed to an inhibition of Gram-positive bacteria which affects acetate, butyrate and ammonia productions in rumen, thus favoring Gram-negative bacteria growth in addition to propionate production. It should be stressed that treatment effects on ruminal microbial population could change the ratio of purines and microbial protein (Fujihara and Shem, 2011). Nevertheless, microbial N synthesis had no differences which could due to setting a fixed ratio between purines and microbial protein during microbial protein production calculations (0.134 N PD/N total microbial; Valadares et al., 1999).

Few studies have approached ruminal fermentation when supplementing with similar FO mixtures to lactating dairy cows. On the other hand, in vitro fermentation studies have shown increased production of propionate using CSNL or CO as supplement. Seradj et al. (2015) performed an in vitro evaluation with the same FO of the current study and reported an increase in the molar proportion of propionate and a decline of $\mathrm{NH}_{3}-\mathrm{N}$ concentration. Watanabe et al. (2010) evaluated increasing doses of raw CNSL on a pure bacterial culture cultivated in rumen fluid-containing medium and found a quadratic positive response, in which propionate is enhanced by increasing the proportions of propionate- and succinateproducing rumen bacteriaa. Stasiuk and Kozubek (2010) suggested that phenolic lipids (as cardanol and cardol) interact with membranes and DNA structures promoting cytotoxic activities responsible for antimicrobial activity. The cardol (a CSNL derivative) has been shown to inhibit the growth of Gram-positive bacteria (Himejima and Kubo, 1991), demonstrating similar activity as a rumen modulator of MON. Shinaki et al. (2012) studied the use of CNSL in diets of non-lactating cows and reported an increase in molar proportion of propionate without altering ruminal $\mathrm{pH}$ and ammonia concentration. Moreover, Ramos Morales et al. (2012) evaluated the addition of ricinoleic acid (a CO component) on bacterial cultures from sheep ruminal digesta and notified an increase of propionate, and a reduction of acetate, butyrate and isovalarate concentration after $24 \mathrm{~h}$ of fermentation.

Both MON and FO increased milk yield without changing nutrient digestibility; therefore, this effect is may be related to ruminal propionate increase. Propionate is the most important substrate for hepatic gluconeogenesis (accounting for 60-74\% total substrate), which is highly associate with milk yielding in cows (Aschenbach et al., 2010; Hammon et al., 2010). Besides of that, glucose is a precursor of lactose, an osmotic constituent of milk, which increases water secretion and consequently milk volume (Miglior et al., 2006). Increasing protein yields have also been observed by high milk production derived from MON and FO addition, without altering milk protein proportion compared to CON. Interestingly, MON decreased the proportion of milk fat compared to CON. Lately, MON has been associated with milk fat depression (McGuffey et al., 2001; Duffield et al., 2003), since it reduces ruminal production of acetate and butyrate (Van Der Werf et al., 1998).

Duffield et al. (2008) performed a meta-analysis of production responses of 77 trials supplementing dairy cows with MON; they found an average increase of $2 \%$ in milk and protein yields, while the current experiment showed raises of $5.0 \%$ and $3.8 \%$ in milk and protein yields, respectively. To our knowledge, this is the first experiment assessing CNSL and CO mixture effects on dairy cattle production; however, these compounds have been already evaluated separately. According to certain 
authors, CNSL supplementation has not effect on milk production of dairy cows (Coutinho et al., 2014; Branco et al., 2015). Gandra et al. (2014) supplemented dairy cows with ricinoleic acid (a CO component) and found an increase of milk yield.

Nitrogen intake and excretion ( $\mathrm{N}$ in feces and urine) were not affected by treatments, since even $\mathrm{N}$ intake and digestibility were similar among all treatments. It is noteworthy that daily urinary volume was based on a fixed creatinine excretion rate $(24.05 \mathrm{mg} / \mathrm{kg} \mathrm{BW})$, assuming that body tissue breakdown was unaffected by neither FO nor MON. Urinary creatinine excretion is little affected by dietary changes, varying only with animal growth rate (Chizzotti et al., 2008). The secretion of $\mathrm{N}$ increased with milk production in cows supplemented with MON or FO compared to CON. Nonetheless, the synthesis of microbial $\mathrm{N}$ was not affected by the treatments, agreeing with Branco et al. (2015), who supplemented lactating cows with CNSL and did not find any differences on N utilization, microbial N synthesis, and blood glucose concentration. Similarly, Vendramini et al. (2016) supplied diets of lactating cows with MON and did not observe differences on microbial $\mathrm{N}$ synthesis and blood profile, including glucose, urea, aspartate-aminotransferase and gamma-glutamyl transferase. Interestingly, blood urea concentration decreased in cows fed FO, suggesting a greater utilization of absorbed CP or a reduction of endogenous protein turnover.

\section{Conclusion}

The mixture of functional oils evaluated in this study had no influence on nutrient intake and digestibility, however, shifted ruminal fermentation towards energetically most efficient routes, increasing propionate production and consequently improving milk yield whether compared to CON. This mixture reduced blood urea concentration; therefore, it may replace MON supplementation in dairy cow diets, without impairing productive performance.

\section{Conflict of interest}

None of the authors of the above manuscript has declared any conflict of interest.

\section{Acknowledgments}

The authors acknowledge the Dairy Cattle Research Laboratory of University of Sao Paulo, for providing the infrastructure and staff necessary for this study. We appreciate the support on the experiment provided by Oligo Basics Agroindustry. In addition, the authors express appreciation to the Brazilian funding agency CAPES ('Coordenação de Aperfeiçoamento de Pessoal de Nivel Superior') for providing the scholarship to E. Ferreira de Jesus.

\section{References}

AOAC, 2000. Official Methods of Analysis, 17th ed. Association of Official Analytical Chemists, Arlington, VA, USA

Akins, M.S., Perfield, K.L., Green, H.B., Bertics, S.J., Shaver, R.D., 2014. Effect of monensin on lactating dairy cow diets at 2 starch concentrations. J. Dairy Sci. 97, 917-929, http://dx.doi.org/10.3168/jds.2013-6756.

Allen, M.S., Bradford, B.J., Oba, M., 2009. The hepatic oxidation theory of the control of feed intake and its application to ruminants. J. Anim. Sci. 87, 3317-3334, http://dx.doi.org/10.2527/jas.2009-1779.

Allen, M.S., 2000. Effects of diet on short-term regulation of feed intake by lactating dairy cattle. J. Dairy Sci. 83, 1598-1624, http://dx.doi.org/10.3168/jds.S0022-0302(00)75030-2.

Aschenbach, J.R., Kristensen, N.B., Donkin, S.S., Hammon, H.M., Penner, G.B., 2010. Gluconeogenesis in dairy cows: the secret of making sweet milk from sour dough. IUBMB Life 62, 869-877, http://dx.doi.org/10.1002/iub.400.

Branco, A.F., Giallongo, F., Frederick, T., Weeks, H., Oh, J., Hristov, A.N., 2015. Effect of technical cashew nut shell liquid on rumen methane emission and lactation performance of dairy cows. J. Dairy Sci. 98, 4030-4040, http://dx.doi.org/10.3168/jds.2014-9015.

Broderick, G.A., Clayton, M.K., 1997. A statistical evaluation of animal and nutritional factors influencing concentrations of milk urea nitrogen. J. Dairy Sci. 80, 2964-2971, http://dx.doi.org/10.3168/jds.S0022-0302(97)76262-3.

Broderick, G.A., Kang, J.H., 1980. Automated simultaneous determination of ammonia and total amino acids in ruminal fluid and in vitro media. J. Dairy Sci. 63, 64-75, http://dx.doi.org/10.3168/jds.S0022-0302(80)82888-8.

Casali, A.O., Detmann, E., Valadares Filho, S.C., 2008. Influência do tempo de incubação e do tamanho de partículas sobre os teores de compostos indigestíveis em alimentos e fezes bovinas obtidos por procedimentos in situ. R. Bras. Zootec. 37, 335-342, http://dx.doi.org/10.1590/S1516-35982008000200021.

Chen, X.B., Gomes, M.J., 1992. Estimation of Microbial Protein Supply to Sheep and Cattle Based on Urinary Excretion of Purine Derivatives-an Overview of Technical Details. Rowett Research Institute, Aberdeen, pp. 21 (Occasional Publication).

Chizzotti, M.L., Valadares, S.C., Valadares, R.F.D., Chizzotti, F.H.M., Tedeschi, L.O., 2008. Determination of creatinine excretion and evaluation of spot urine sampling in Holstein cattle. Livest. Prod. Sci. 113, 218-225, http://dx.doi.org/10.1016/j.livsci.2007.03.013.

Coutinho, D.A., Branco, A.F., Santos, G.T., Osmari, M.P., Teodoro, A.L., Diaz, T.G., 2014. Intake, digestibility of nutrients, milk production and composition in dairy cows fed on diets containing cashew nut shell liquid. Acta Sci. 36, 311-316, http://dx.doi.org/10.4025/actascianimsci.v36i3.23512.

Cruz, O.T., Valero, M.V., Zawadzki, F., Rivaroli, D.C., Prado, R.M., Lima, B.S., Prado, I.N., 2014. Effect of glycerin and essential oils (Anacardium occidentale and Ricinus communis) on animal performance, feed efficiency and carcass characteristics of crossbred bulls finished in a feedlot system. Ital. J. Anim. Sci. 13, 790-797, http://dx.doi.org/10.4081/ijas.2014.3492.

Duffield, T.F., LeBlanc, S., Bagg, R., Leslie, K., Ten Hag, J., Dick, P., 2003. Effect of a monensin controlled release capsule on metabolic parameters in transition dairy cows. J. Dairy Sci. 86, 1171-1176, http://dx.doi.org/10.3168/jds.S0022-0302(03)73700-X.

Duffield, T.F., Rabiee, A., Lean, I.J., 2008. A meta-analysis of the impact of monensin in lactating dairy cattle. Part 2. Production effects. J. Dairy Sci. 91, 1347-1360, http://dx.doi.org/10.3168/jds.2007-0608.

Ferreira, C.M., Rosa, O.P.S., Torres, S.A., Ferreira, F.B.A., Bernadinelli, N., 2002. Activity of endodontic antibacterial agents against selected anaerobic bacteria. Braz. Dent. J. 13, 118-122, http://dx.doi.org/10.1590/S0103-64402002000200008.

Fujihara, T., Shem, M.N., 2011. Metabolism of microbial nitrogen in ruminants with special reference to nucleic acids. Anim. Sci. J. 82, 198-208, http://dx.doi.org/10.1111/j.1740-0929.2010.00871.x. 
Gandra, J.R., Nunes Gil, P.C., Gandra, E.R.S., Del Vale, T.A., Barletta, R.V., Zanferari, F., Ferreira de Jesus, E., Takiya, C.S., Mingoti, R.D., Almeida, G.F., Paiva, P.G., Gobesso, A.A.O., 2014. Productive performance of Simmental dairy cows supplemented with ricinoleic acid from castor oil. Arch. Zootec 63, 575-585, http://dx.doi.org/10.4321/S0004-05922014000400002.

Hall, M.B., 2000. Calculation of Non-structural Carbohydrate Content of Feeds That Contain Non-protein Nitrogen. University of Florida, pp. A-25 (Bulletin 339).

Hamad, F.B., Mubofu, E.B., 2015. Potential biological applications of bio-based anacardic acids and their derivatives. Int. J. Mol. Sci. 16, 8569-8590, http://dx.doi.org/10.3390/ijms16048569.

Hammon, H.M., Metges, C.C., Schulz, A., Junghans, P., Steinhoff, J., Schneider, F., Pfuhl, R., Bruckmaier, R.M., Weikard, R., Kuhn, C., 2010. Differences in milk production, glucose metabolism, and carcass composition of 2 charolais $\times$ holstein $\mathrm{F}_{2}$ families derived from reciprocal paternal and maternal grandsire crosses. J. Dairy Sci. 93, 3007-30018, http://dx.doi.org/10.3168/jds.2009-2931.

Himejima, M., Kubo, I., 1991. Antibacterial agents from the cashew Anacardium occidentale (Anacardiaceae) nut shell oil. J. Agric. Food Chem. 39, 418-421, http://dx.doi.org/10.1021/jf00002a039.

Ipharraguerre, I.R., Clark, J.H., 2003. Usefulness of ionophores for lactating dairy cows: a review. Anim. Feed Sci. Technol. 106, 30-57, http://dx.doi.org/10.1016/S0377-8401(03)00065-8.

McGuffey, R.K., Richardson, L.F., Wilkinson, J.I.D., 2001. Ionophores for dairy cattle: current status and future outlook. J. Dairy Sci. 84 (suppl), 194-203, http://dx.doi.org/10.3168/jds.S0022-0302(01)70218-4.

Miglior, F., Sewalem, A., Jamrozik, J., Lefebvre, D.M., Moore, R.K., 2006. Analysis of milk urea nitrogen and lactose and their effect on longevity in Canadian dairy cattle. J. Dairy Sci. 89, 4886-4894, http://dx.doi.org/10.3168/jds.S0022-0302(06)72537-1.

Murakami, A.E., Eyng, C., Torrent, J., 2014. Effects of functional oils on coccidiosis and apparent metabolizable energy in broiler chickens. Asian-Australas. J. Anim. Sci. 27, 981-989, http://dx.doi.org/10.5713/ajas.2013.13449.

Nocek, J.E., 1988. In situ and other methods to estimate ruminal protein and energy digestibility: a review. J. Dairy Sci., 2051-2069, http://dx.doi.org/10.3168/jds.S0022-0302(88)79781-7.

NRC, 2001. National Research Council. Nutrient Requirements of Dairy Cattle, 7. ed. National Academic Press, Washington, D.C.

Orellana Boero, P., Balcells, J., Martín-Orúe, S.M., Liang, J.B., Guada, J.A., 2001. Excretion of purine derivatives in cows: endogenous contribution and recovery of exogenous purine bases. Livest. Prod. Sci. 68, 243-250, http://dx.doi.org/10.1016/S0301-6226(00)00231-1.

Prado, I.N., Cruz, O.T.B., Valero, M.V., Zawadzki, F., Eiras, C.E., Rivaroli, D.C., Prado, R.M., Visentainer, J.V., 2015a. Effects of glycerin and essential oils (Anacardium occidentale and Ricinus communis) on the meat quality of crossbred bulls finished in a feedlot. Anim. Prod. Sci., http://dx.doi.org/10.1071/AN14661.

Prado, R.M., Côrtes, C., Benchaar, C., Petit, H.V., 2015b. Interaction of sunflower oil with monensin on milk composition, milk fatty acid profile, digestion, and ruminal fermentation in dairy cows. Anim. Feed Sci. Technol. 207, 85-92, http://dx.doi.org/10.1016/j.anifeedsci.2015.06.017.

Purevjav, T., 2011. Effects of functional oils and monensin on cattle finishing programs. In: Thesis. Iowa State University, Ames, Iowa, pp. 106.

Ramos Morales, E., Mata Espinosa, M.A., McKain, N., Wallace, R.J., 2012. Ricinoleic acid inhibits methanogenesis and fatty acid biohydrogenation in ruminal digesta from sheep and in bacterial cultures. J. Anim. Sci. 90, 4943-4950, http://dx.doi.org/10.2527/jas.2011-4670.

Raun, A.P., Cooley, C.O., Potter, E.L., Richardson, L.F., Rathmacher, R.P., Kennedy, R.W., 1974. Effect of monensin on feed efficiency of cattle. J. Anim. Sci. 39, 350 (Abstr.)

Russell, J.B., 1996. Mechanisms of ionophore action in ruminal bacteria. In: Scientific Update on Rumensin/Tylan/Micotil for the Professional Feedlot Consultant. Lilly Corporate Center, pp. E1-E18.

Seradj, A.R., Torrent, J., de la Fuente, G., Balcells, J., 2015. In vitro effects of a commercial blend of functional oils on rumen fermentation, methane production, and methanogenic archae. J. Anim. Sci. 93 (3), 162 (Abstr.)

Shinaki, T., Enish, O., Mitsumori, M., Higuchi, K., Kobayashi, Y., Takenaka, A., Nagashima, K., Mochizuki, M., Kobayashi, Y., 2012. Mitigation of methane production from cattle by feeding cashew nut shell liquid. J. Dairy Sci. 95, 5308-5316, http://dx.doi.org/10.3168/jds.2012-5554.

Sklan, D., Ashkennazi, R., Braun, A., Devorin, A., Tabori, K., 1992. Fatty acids, calcium soaps of fatty acids, and cottonseeds fed to high yielding cows. J. Dairy Sci. 75, 2463-2472, http://dx.doi.org/10.3168/jds.S0022-0302(92)78008-4.

Stasiuk, M., Kozubek, A., 2010. Biological activity of phenolic lipids. Cell Mol. Life Sci. 67, 841-860, http://dx.doi.org/10.1007/s00018-009-0193-1.

Trevisan, M.T.S., Pfundstein, B., Haubner, R., Wirtele, G., Spiegelhalder, B., Bartsch, H., Owem, R.W., 2006. Characterization of alkyl phenols in cashew (Anacardium occidentale) products and assay of their antioxidant capacity. Food Chem. Toxicol. 44, 188-197, http://dx.doi.org/10.1016/j.fct.2005.06.012.

Valadares, R.F.D., Broderick, G.A., Valadares Filho, S.C., Clayton, M.K., 1999. Effect of replacing alfalfa silage with high moisture corn on ruminal protein synthesis estimated from excretion of total purine derivatives. J. Dairy Sci. 82, 2686-2696, http://dx.doi.org/10.3168/jds.S0022-0302(99)75525-6.

Valero, M.V., Prado, R.M., Zawadzki, F., Eiras, C.E., Madrona, G.S., Prado, I.N., 2014. Propolis and essential oils additives in the diets improved animal performance and feed efficiency of bulls finished in feedlot. Acta Scientiarum 36, 419-426, http://dx.doi.org/10.4067/S0718-58392014000400011.

Van Der Werf, J.H.J., Jonker, L.J., Oldenbroek, J.K., 1998. Effect of monensin on milk production by Holstein and Jersey cows. J. Dairy Sci. 81, 427-433, http://dx.doi.org/10.3168/jds.S0022-0302(98)75593-6.

Van Nevel, C.J., Demeyer, D.I., Henderickx, H.K., 1971. Effect of fatty acid derivatives on rumen methane and propionate in vitro. App. Microbiol. 21, 365-366.

Van Soest, P.J., Robertson, J.B., Lewis, B.A., 1991. Methods for dietary fiber neutral detergent fiber, and non-starch polysaccharides in relation to animal nutrition. J. Dairy Sci. 74, 3583-3597.

Vendramini, T.H.A., Takiya, C.S., Silva, T.H., Zanferari, F., Rentas, M.F., Bertoni, J.C., Consentini, C.E.C., Gardinal, R., Acedo, T.S., Rennó, F.P., 2016. Effects of a blend of essential oils, chitosan or monensin on nutrient intake and digestibility of lactating dairy cows. Anim. Feed Sci. Technol. 214, 12-21, http://dx.doi.org/10.1016/j.anifeedsci.2016.01.015.

Vieira, C., Evangelista, S., Cirillo, R., Lippi, A., Maggi, C.A., Mazini, S., 2000. Effect of ricinoleic acid in acute and subchronic experimental models of inflammation. Mediators Inflammation 9, 223-228, http://dx.doi.org/10.1080/09629350020025737.

Watanabe, Y., Suzuki, R., Koike, S., Nagashima, K., Mochizuki, M., Forster, R.J., Kobayashi, Y., 2010. In vitro evaluation of cashew nut shell liquid as a methane-inhibiting and propionate-enhancing agent for ruminants. J. Dairy Sci. 93, 5258-5267, http://dx.doi.org/10.3168/jds.2009-2754.

Weiss, W.P., Conrad, H.R., Pierre, N.R.S., 1992. A theoretically-based model for predicting total digestible nutrient values of forages and concentrates. Anim. Feed Sci. Technol. 39, 95-110, http://dx.doi.org/10.1016/0377-8401(92)90034-4. 